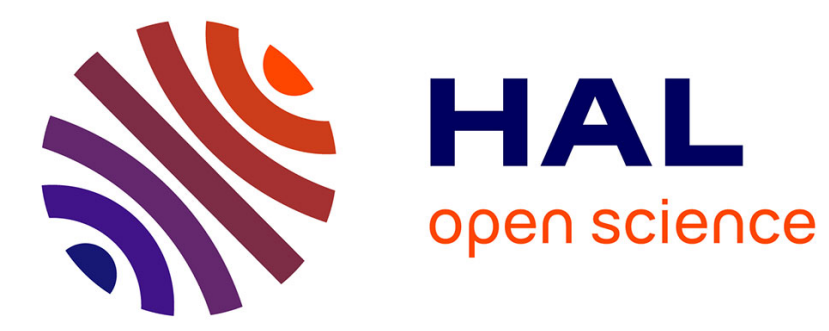

\title{
The heterogeneous effect of international outsourcing on firm productivity
}

Fergal Mccann

\section{To cite this version:}

Fergal Mccann. The heterogeneous effect of international outsourcing on firm productivity. Review of World Economics, 2010, 147 (1), pp.85-108. 10.1007/s10290-010-0080-8 . hal-00642402

\section{HAL Id: hal-00642402 \\ https://hal.science/hal-00642402}

Submitted on 18 Nov 2011

HAL is a multi-disciplinary open access archive for the deposit and dissemination of scientific research documents, whether they are published or not. The documents may come from teaching and research institutions in France or abroad, or from public or private research centers.
L'archive ouverte pluridisciplinaire $\mathbf{H A L}$, est destinée au dépôt et à la diffusion de documents scientifiques de niveau recherche, publiés ou non, émanant des établissements d'enseignement et de recherche français ou étrangers, des laboratoires publics ou privés. 


\title{
The heterogeneous effect of international outsourcing on firm productivity
}

\author{
Fergal McCann*ł \\ Université Paris 1, Panthéon-Sorbonne
}

October 28,2010

\begin{abstract}
This paper analyses how international outsourcing affects plant total factor productivity (TFP) using a census of Irish manufacturing firms. The results point to a striking pattern: the status of being or becoming an outsourcer matters strongly for firms that are indigenous and not exporting, while for exporters and foreign affiliates, TFP increases are lower, insignificant and sometimes negative. On the other hand, higher intensity of outsourcing matters for both exporters and foreign affiliates. The message is clear: international outsourcing's initial learning effect on TFP is most pronounced when it serves as a first exposure to international markets, while the "scale effect" of outsourcing en masse only occurs to larger, already internationalised firms.
\end{abstract}

JEL Classifications: F10, F23, L23

Keywords: Outsourcing, Imports of Inputs, Productivity, Firm Structure

${ }^{*}$ Corresponding address: Bureau 316, Maison des Sciences Economiques, 106 - 112 Boulevard de L'Hopital, 75647 Paris cedex 13, France.

${ }^{\dagger}$ Corresponding phone number: +33 650366717

‡fergaljmccann@gmail.com, fergal.mccann@univ-paris1.fr 


\section{Introduction}

One would expect that the inter-firm importing of intermediates, or international outsourcing, would lead to increases in firms' total factor productivity (TFP) for a number of reasons. Feenstra and Hanson (1996) consider a good produced in multiple stages, any of which can be moved offshore. Stages intensive in unskilled labour will be moved to countries with lower relative wages for unskilled labour. One strong possibility is that TFP is increased due to the lower costs of the inputs produced abroad, due to factor price differentials, and economies of scale due to specialisation of another country in the particular input. The stages that remain at home can then be aggregated into a production function, with the foreign-produced stages entering the production function as an additional input. Moreover, the stages remaining at home will likely be the "value-adding" stages of production that require more skilled labour. As an example of the potential within-firm reallocation that international outsourcing can allow, Görg and Hanley (2009) show that firms that engage in more international sourcing of services engage in more research and development (R\&D).

Furthermore, an increased variety of inputs available on the world market compared to the local market should give a higher likelihood of finding the input that perfectly fits the firm's production process (as in the "market thickness" effect of theoretical papers such as Grossman and Helpman (2003)). Given the higher number of inputs available once a firm enters the import market, the quality of inputs should also rise, particularly for firms located where domestic producers are not up to international standards. Similarly, one may assert that there is a certain technological advantage embedded in international intermediate inputs, due to firm interaction with foreign dealers who may possess a higher level of expertise. Another way of putting it, as in Keller (2004, pp 755) is that

... employing a foreign intermediate good in final-output production involves the implicit usage of the technology in embodied form. There is a spillover in this process of international technology diffusion to the extent that the intermediate good costs less than its opportunity costs - which include the $\mathrm{R} \& \mathrm{D}$ costs of product development.

In this paper I empirically assess the role that international outsourcing of material inputs ${ }^{1}$ plays in increasing firm productivity. Before moving on to estimate the effect of outsourcing on TFP, I first show that outsourcing must be treated as an endogenous variable. In order to show this, I turn to the literature on exporting originating with Bernard and Jensen's (1999) (BJ henceforth) paper on the selection into versus learning from exporting to attempt to estimate a selection effect into international outsourcing. From the pool of non-outsourcers at a given time $t-1$, I show that the more productive firms do indeed select into the international outsourcing market. Given this endogenous entry of

\footnotetext{
${ }^{1}$ Data limitations prevent the analysis of international services outsourcing.
} 
more productive firms into the intermediate import market, it is clear that causality may run both ways in the outsourcing-productivity relationship.

I distinguish at all times between international outsourcing and intra-firm trade, as productivity effects that come from purchasing from a headquarter may involve transfer of firm-specific knowledge, rather than the effects that I have outlined above. For this reason, in all empirical analysis, only firms that source from outside their firm boundary are considered.

The empirical analysis of outsourcing's effect on TFP allows outsourcing to be captured in two different ways, with the aim of illustrating how differing these two approaches are in the mechanisms they are set up to capture, and in the results at which they arrive. Outsourcing, either measured as outsourcing intensity (imported material inputs over the total wage bill) or as a binary outsourcing status variable, is included in a firm-level production function in logs. Fixed effects, difference GMM (Arellano and Bond, 1991), system GMM (Blundell and Bond, 1998) and a modified version of the Olley and Pakes (1996) (OP henceforth $)^{2}$ structural estimator are used as methods to estimate the production function.

If, as in Gorzig and Stephan (2002), Görg et al. (2004), Görg and Hanley (2005), Hijzen et al. (2010) and Görg et al. (2008), we treat outsourcing as a continuous variable, using the firm's outsourcing intensity as an independent variable that enters into a Cobb-Douglas production function, we arrive at the conclusion that more international outsourcing leads to productivity gains for foreign owned firms and for indigenous exporters in Ireland. This is broadly in line with the findings of Görg et al. (2008), who find that being more embedded in international markets leads to larger productivity gains from outsourcing.

I propose that if international outsourcing is treated as a binary variable, different results should be arrived at. Under certain estimation techniques, the usage of a binary outsourcing measure amounts to testing the effect of switching into outsourcing on productivity. This discrete variable approach is grounded in the idea that becoming an outsourcer may lead to a fundamental change in the way a firm operates. The discrete variable also allows outsourcing to be used as a "treatment" in propensity score matching (PSM) techniques, estimating difference in difference (DD) effects for outsourcing on TFP.

All analysis of the binary variable gives the intuitive result that indigenous nonexporters benefit the most from being an international outsourcer. For indigenous ex-

\footnotetext{
${ }^{2}$ This estimator complements the work of De Loecker (2007) and Amiti and Konings (2007) which allowed the firm's export and import status, respectively, to affect its investment decisions and probability of survival. For further explanation of the estimation procedure, see Appendix 1.
} 
porters and foreign affiliates, the effect of outsourcing on productivity is either lower, insignificant or negative. The intuition for the results stems from the idea of a "productivity ordering" of international activities. Indigenous exporters and multinational affiliates are likely to have exhausted a lot of the potential for productivity improvement due to the selection effects and the learning effects from entering into these activities. They are unlikely to experience as large a fundamental shift in the way they operate due to their being an importer of intermediates. Indigenous non-exporting firms, on the other hand, are further down the "productivity chain" so to speak, and are, therefore, more likely to benefit from being an international outsourcer relative to similar firms who only source inputs at home. Thus it is as a first step into international trade that becoming an outsourcer leads to the largest productivity improvements.

Papers that embed the decision to import intermediates in the estimation of a firm production function include Amiti and Konings (2007) and Kasahara and Rodrigue (2008), who both find that importing of intermediates leads to increased productivity for Indonesia and Chile, respectively. The latter applies both a discrete and continuous measure of outsourcing and finds both to have positive significant effects on productivity. The approach taken in Section 4.2 and 4.3 is very similar to that in Kasahara and Rodrigue (2008), but can be seen as an extension, given that they do not break heterogeneous firms down by their internationalisation status. The analysis here, by breaking firms down along the delineation of Helpman, Melitz and Yeaple (2004, HMY henceforth), gives more insight into the detail of the productivity improvement brought about due to outsourcing. Lopez (2006), in related work, shows that importer status positively predicts plant survival in Chile.

The topic of international outsourcing has grown exponentially in relevance in the last two decades. As Grossman and Helpman (2005, pp. 135) state, "we live in an age of outsourcing". The reasons for the onset of this "age of outsourcing" lie in what Baldwin (2006) refers to as globalisation's "second unbundling". He defines the first unbundling as being marked by industrialisation, trade, growth, urbanisation and increasing internal inequality in the North. The firm was considered a "black box", and firm-to-firm competition was the lowest level of aggregation to be analysed. In Baldwin's "second unbundling", which began in the 1980s, that "black box" was opened up, as firms started to locate different parts of the production process in different locations. The lowest level of disaggregation was no longer the firm but the task. Myriad factors can explain this shift in the process of production. These factors are well documented in the literature. For the purpose of all analysis that follows I define outsourcing as the procurement of inputs to the production process from outside the boundary of the firm (see Section 2, Figure 1).

To the best of my knowledge, this is the first study to look at both outsourcing status 
and intensity and test their effect on the productivity of heterogeneous firm types. It is also the first paper to my knowledge to have tested the selection and learning equations proposed by BJ for outsourcing, using a structurally estimated TFP measure and propensity score matching. The paper can be viewed as an extension of Görg et al. (2008), in that it also looks at the heterogeneous effect of outsourcing for domestic, exporting and foreign firms, but looks at both outsourcing intensity and outsourcing status. It can also be seen as an extension of Kasashara and Rodrigue (2008) in that it looks at both out-

sourcing intensity and status, but also looks at the effect for heterogeneous firms. The intuitive nature of the differing results, depending on the measure of outsourcing used, comprises an addition to the literature's understanding of the importance of both the importing of intermediates and international trade in general to firm performance.

The paper proceeds as follows. The reasons to expect a causal relationship from outsourcing (both in general and offshore) to firm-level productivity are outlined in Section 2. Section 3 explains the data source, the Census of Industrial Production, and offers descriptive statistics. Section 4 reports regression results, while Section 5 concludes.

\section{Theoretical motivation}

Firms make sourcing decisions along two dimensions; the firm boundary and location. The decision matrix in Figure 1 is borrowed from Olsen (2006). The bottom right-hand corner of the matrix, where firms source from affiliates abroad, is more commonly referred to as intra-firm trade, associated with foreign direct investment (FDI), usually of exportplatform or vertical nature. Consider a firm that has been sourcing its inputs purely domestically, either by producing all inputs in its own plant (bottom left-hand corner), or by combining this with sourcing from local plants (top left hand corner). When a firm outsources internationally, one or a range of its production stages is moved offshore, to a non-affiliated supplier. This implies that some of their production moves from the left-hand side of the matrix to the top-right hand corner. This range of inputs are now removed from the production process at home, and the production function is composed of the activities that occur at home, with the inputs produced abroad entering as a separate input. TFP can be expected to increase in this instance due to the lower cost of producing and shipping the inputs in the top right-hand corner, along with the potential for these inputs to come with foreign technologies embedded.

The data for this paper do not allow analysis along all four of these sourcing modes. By asking firms the percentage of their material inputs that are imported, the data allow concise analysis along the top line of this matrix, when firms that purchase from affiliates, are excluded, i.e. domestic versus international outsourcing. By asking the percentage of purchases coming from affiliates, it allows analysis along the left-hand vertical column for non-importers, i.e. domestic outsourcing versus domestic in-house. The data does 
Figure 1: Firms' sourcing modes

not break imports down into international outsourcing and intra-firm trade, which means that analysis along the bottom row or the right-hand-side column is not possible.

There are a number of theoretical models that offer suggestions as to the expected productivity ordering of different sourcing modes in the data. Two of the broad strands of theoretical literature are the propriety rights, as in Antràs (2003) and Antràs and Helpman (2004) and incentive systems approaches, as in Grossman and Helpman (2002, 2003). The firm incorporates the behaviour of the input supplier into its profit-maximisation decision, in the former due to imperfect contract enforcement, and in the latter due to imperfect opportunities to monitor the supplier. Both of these approaches allow for high fixed costs of entry to either sourcing mode. The productivity rankings in these models depend greatly on the parameters of the model, and imply nothing about the causality from sourcing choice to productivity. On the contrary, they explain more the sorting of firms into sourcing modes based on their productivity, i.e. selection in the parlance of the exporting literature originating with BJ. In Antràs and Helpman (2004), in-house production is associated with higher productivity, while in Grossman and Helpman (2002, 2003), outsourcing is associated with higher productivity. The consistent feature of the literature is that more productive firms, regardless of sourcing mode along the firm boundary, source inputs abroad.

The above-mentioned models explain selection into outsourcing based on TFP. Causality in the other direction, i.e. the productivity-enhancing effect of outsourcing (in general, not specifically international) can be explained theoretically through models such as principal-agent frameworks and transaction cost theory. The former suggests that outsourcing will increase productivity as it limits opportunism and self-serving behaviour on behalf of employees. In this context, output can be better controlled and inefficiencies minimized through a contract than within the boundaries of the firm, so outsourcing is chosen. The latter theory suggests that outsourcing is subject to certain costs such as search costs, contract incompleteness and relationship-specific investment. If these costs are outweighed by the savings from specialization which outsourcing offers, then a firm will decide to outsource. Grossman and Helpman (2003) and others point out that this characteristic of outsourcing is more easily exploitable the "thicker" the outsourcing market. The logic is that the more input suppliers there are in a given country, the higher the likelihood of finding a supplier that matches the needs of the final-good-producing firm. This idea brings us back to the most basic of explanations for the incentive to outsource: simple Smithian specialisation. When a firm outsources a low-value activity such as its call centre or the manufacture of a basic input, it can then reallocate resources into other activities at which it is better, often referred to in the management literature as its "core 
competencies". Outsourcing can also help firms in smoothing out seasonal fluctuations in economic activity, which means that excess spending on unnecessary labour is avoided.

International outsourcing may lead to further productivity gains above and beyond those for outsourcing from within the home country. These reasons are outlined at the beginning of Section 1. Amiti and Wei (2006) cite the increase in the variety of inputs acquired from international outsourcing as one channel of increased productivity. The increased variety means that, in the "market thickness" framework mentioned above, the probability of finding an input provider with the "perfect fit" increases. With an increased variety of inputs will often come an increased quality of input. Thus, the firm's technology frontier also shifts with workers becoming more efficient through exposure to more sophisticated technologies embedded in these inputs. The procurement of inputs from abroad can also lead to "learning by doing" effects for employees exposed to new methods. This is akin to the argument proposed by Keller (2004) in summarising the role of importing in international technology diffusion. Furthermore, inputs sourced from abroad may be sourced to avail of cost differentials. All of these effects suggest that international outsourcing may have a supplementary effect beyond the general productivity-enhancing effects of sourcing an input from outside the firm mentioned in the previous paragraph.

\section{$3 \quad$ Data and descriptive statistics}

The data set used is the Census of Industrial Production (CIP), which is collected each year by the Central Statistics Office (CSO) of Ireland. It is compulsory, giving plant and enterprise-level information on all manufacturing firms with 3 or more persons engaged in Ireland from 1991 to 2005. The majority of the analysis in this paper will focus on the years 2001 to 2005 , as these are the only years for which information on purchases from affiliates is asked of the firms. This allows the identification of firms that are outsourcing as opposed to firms that are simply importing, which could include intra-firm trade. All empirical analysis in Section 4 will exclude firms that are purchasing material inputs from an affiliate, so that the effect of intra-firm knowledge transfer is eliminated, and the clean effect of arm's length outsourcing from abroad is identified. Industry breakdown at the 2, 3 and 4 digit level is given in accordance with NACE Rev 1 from 1991-2001 and NACE Rev 1.1 from 2002 to 2005 . The panel is unbalanced, with sample size for each year fluctuating between 4,500 and 5,000 plants. All monetary variables have been deflated using the CSO's Consumer Price Index Annual \% Changes table, with 1991 used as the base year. Labour input, $l$, is measured as the number of employees, capital $k$ and material inputs $m$, are measured in euro values.

In Table 1, the international orientation of firms in the data is outlined. We see that, in line with expectations, given the fact that Ireland is well known as a hub for export 
platform FDI, $90 \%$ of foreign-owned firms ${ }^{3}$ export. For Irish-owned firms, roughly half of them export some of their output. A similar amount of foreign-owned firms import some of their material imports, compared with just $30 \%$ of Irish-owned firms.

Table 1: International orientation of firms in Ireland

\begin{tabular}{rrr}
\hline & Irish-owned & Foreign-owned \\
\hline Non-Exporter & $50 \%$ & $6 \%$ \\
Exporter & $50 \%$ & $94 \%$ \\
& & \\
Non-importer & $31 \%$ & $9 \%$ \\
Importer & $69 \%$ & $91 \%$ \\
\hline
\end{tabular}

The key variables of interest to this study are those that ask whether a firm's input purchases are imported or not, and whether the firm's purchases are from an affiliate or not. As the census does not ask whether the affiliates are located abroad or not, this study is limited from fully analysing sourcing modes along the lines of Antràs and Helpman (2004). Rather, comparisons can only be made along two dimensions:

- $I N_{D}$ vs $O S_{D}$, for non-importers

- $O S_{F}$ vs $O S_{D}$, for firms with no affiliate purchases

where $I N$ refers to purchases from affiliates only, $O S$ refers to arm's length purchases, or outsourcing, subscript $D$ refers to purchases in Ireland, and subscript $F$ refers to imports. Given reports from the state industrial policy agency Forfás ${ }^{4}$ that between 2002 and 2006 there were 212 outward direct investments from Ireland, only 55 of which were in manufacturing, it can be reasonably assumed that the majority of imports by Irish-owned firms were not intra-firm but rather through outsourcing. Nevertheless, in the empirical section the sample will be restricted to firms that had zero affiliate purchases to ensure that only the effects of outsourcing are picked up. Table 2 breaks the outsourcing dummy, affiliate dummy and continuous outsourcing measure down by the categories analysed in HMY:

- Domestic: Indigenous Irish firms that only serve the domestic market

- Export: Indigenous Irish firms that serve international markets

- Foreign: Multinational affiliates

The data show importing is more common among foreign-owned firms and indigenous exporters (around 85-90\% of both categories import some of their inputs) than among

\footnotetext{
${ }^{3}$ Firms are reported as "foreign-owned" if the "ultimate beneficial owner" of the firm is located outside Ireland.

4 "Outward Direct Investment and the Irish Economy", 2007.
} 
indigenous non-exporters (of which roughly half import). This is to be expected given the complementarities between the two methods of engagement in international trade. The picture is different when examining the percentage of firms that purchase some input from affiliates (information on whether the affiliate is in Ireland or abroad is not available). Amongst indigenous Irish firms, regardless of their export status, less than a fifth purchase inputs from an affiliate. On the other hand, almost half of foreign firms purchase from an affiliate. This is again to be expected, as it is hard to imagine a majority of indigenous Irish manufacturing firms being members of large corporate groups, as evidenced by the Forfás policy report mentioned above. OSint ${ }^{5}$, foreign outsourcing intensity, which is calculated as the euro amount of inputs sourced from abroad divided by the firm's total wage bill, is highest for foreign firms, followed by exporters, followed by domestic firms, as should be expected. I calculate the intensity relative to the wage bill as it gives a better sense of the degree of (an inverse measure of) vertical integration of the firm than a simple measure of the percentage of total purchases imported.

Table 2: Percentage of firms engaging in international outsourcing and purchases from affiliates, international outsourcing intensity, by HMY

\begin{tabular}{lrrrrr}
\hline & \multicolumn{3}{c}{ Importer? } & Affiliate? & OSint \\
\hline & No & Yes & No & Yes & \\
Indigenous Domestic & 48 & 52 & 89 & 11 & 0.7815 \\
Indigenous Exporter & 14 & 86 & 82 & 18 & 1.5962 \\
Foreign Affiliates & 9 & 91 & 57 & 43 & 3.1489 \\
\hline
\end{tabular}

The predictions of the HMY paper and others suggest that foreign firms should outperform exporters, who should outperform domestic firms along any number of firm characteristics. The reason for this lies in the theory emanating from Melitz (2003) regarding the fixed entry costs to international activity. The Irish data confirm that foreign firms have higher sales, are larger, use more capital ${ }^{6}$, more materials and more services than exporters, who in turn use more of each than domestic firms. Now that a picture of the trends in the data has been painted, Section 4 will test for the causal effect of outsourcing on productivity.

\footnotetext{
${ }^{5}$ This includes "Raw Materials, Materials for repairs, Materials purchased for the production of capital goods by your enterprise for your own use, Packaging, Office supplies".

${ }^{6}$ The CIP does not report capital stock figures. To get around this problem, changes in capital stock were regressed on differences in energy usage for each year at the NACE2 level, with the resulting parameter applied to levels of energy usage to get a proxy for capital stock.
} 


\section{Empirics}

\subsection{Endogeneity}

The theoretical framework of Melitz (2003) and HMY suggest that firms may engage in international activity due to their higher productivity. With this in mind, we should fear the possibility that causality between outsourcing and TFP runs in both directions. If fixed costs to international outsourcing exist, such as search costs for a supplier abroad, reputational costs etc., it may be the case that only the more productive firms engage in outsourcing. In Ireland we may also think of international outsourcing as a way of cutting out the middleman. Considering that a large amount of inputs are imported in Ireland, it may be the case that even a lot of domestic purchases are actually purchases of imported goods from a middleman, i.e. a retailer or wholesaler, who will obviously be taking a margin on the sale. Importing directly from the input provider cuts out the middleman and thus may ensure a better deal for the purchaser. We can again imagine that it is easier for larger, more productive firms to go directly to the input provider as opposed to purchasing from a wholesaler in Ireland.

To test whether this endogeneity indeed exists, I run a selection regression in the spirit of BJ. A random effects probit regression of all firms that are non-outsourcers at $t-1$ is run, to examine whether productivity at $t-1$ and $t-2$ significantly influences the probability of becoming an outsourcer at $t$. The following model is run:

$$
\operatorname{Pr}\left(O S_{i t}=1 \mid O S_{i, t-1}=0\right)=F\left(\Phi_{i, t-1}+\delta_{s}+\delta_{t}+e_{i t}\right)
$$

where $\Phi$ includes productivity, ownership, age and $\delta_{s}$ and $\delta_{t}$ are industry and time dummies. In Column (1) and (2) of Table 3, Equation 1 above is tested for selection to outsourcing. Column 1 tests the equation for all firms that were non-importers at $t-1$, and is thus subject the problem that firms engaging in intra-firm trade might be included in the sample. To test for cleaner effects, Column 2 restricts the sample to firms that were non-importers at $t-1$, and never purchasers from affiliates, thus ruling out firms engaging in intra-firm trade. This, therefore, tests selection into international outsourcing cleanly. Column 2 finds indeed that firms that begin to outsource internationally at $t$ are more productive, but only two years before entry, than those that stay sourcing domestically. The differing results show that it is important to make the distinction between importers and outsourcers, as the former includes firms that purchase from affiliates. The transfer of knowledge within the firm is not what is being tested in this paper. For this reason, international outsourcing, taken as imports by firms who do not purchase from affiliates, as in Column 2 below, is the focus of all regression analysis from now on.

Table 3: Selection into importing and international outsourcing, RE Probit 


\begin{tabular}{rcc}
\hline & $\begin{array}{c}\text { importing } \\
(1)\end{array}$ & $\begin{array}{c}\text { outsourcing } \\
(2)\end{array}$ \\
\hline$T F P_{t-1}$ & $0.7425^{*}$ & 0.4583 \\
& $(0.4327)$ & $(0.4547)$ \\
$T F P_{t-2}$ & $0.9450^{* *}$ & $1.1457^{* * *}$ \\
& $(0.4061)$ & $(0.4252)$ \\
ctry & $-0.3226^{*}$ & -0.2876 \\
& $(0.1911)$ & $(0.2021)$ \\
age & $0.0362^{* * *}$ & $0.0423^{* * *}$ \\
& $(0.0106)$ & $(0.0115)$ \\
Constant & $-10.0024^{* * *}$ & $-9.2088^{* * *}$ \\
& $(1.8332)$ & $(1.8629)$ \\
Observations & 3,903 & 3,492 \\
\hline Standard errors in parentheses \\
Time and industry dummies included \\
*** $p \leq 0.01, * * p \leq 0.05,{ }^{*} p \leq 0.1$ \\
\hline
\end{tabular}

\subsection{Outsourcing as a continuous variable}

As in Gorzig and Stephan (2002), Görg et al. (2004), and Görg and Hanley (2005), Hijzen et al. (2010) and Görg et al. (2008), I first treat outsourcing as a continuous variable. This section is very close to the analysis of Görg et al. (2008), who also identify heterogeneous effects for domestic, exporting and foreign-owned firms and find that only internationalised firms benefit from increased outsourcing, and that the benefit is limited to outsourcing of services. Differently from the former paper, the data used here are census data, thus leading to a more complete analysis of the Irish manufacturing sector. As mentioned above, the census data do not require firms to break services purchases down by imported and domestic purchases, thus leaving the analysis restricted to the international outsourcing of material inputs. In both this and Section 4.3, I estimate the following production function in logs, similar to that used by Kasahara and Rodrigue (2008) and Görg et al. (2008):

$$
y_{i t}=\alpha_{0}+\beta_{l} l_{i t}+\beta_{k} k_{i t}+\beta_{m} m_{i t}+\beta_{i} i_{i t}+\epsilon_{i t}
$$

where $l$ is the number of employees, $k$ is capital stock, $m$ is material inputs and $\beta_{i} i_{i t}$ can take the form of outsourcing intenstity or the firm's outsourcing status, a $(0,1)$ variable. The crucial component of either model is the treatment of the error term, which is assumed to be composed of a "productivity component", $\omega_{i t}$ and an i.i.d. error, $\eta_{i t}$. As shown in Section 4.1, we have reason to believe that the $\omega_{i t}$ component may be correlated with the decision to outsource. In the regression analysis to follow, I adopt several methods to deal with this endogeneity. The first is to assume that the outsourcing/error term correlation is constant over time within each firm and run the within-effects or fixed effects (FE) estimator. The second is to instrument for the endogeneity of outsourcing by running a first-difference model, using lagged levels as an instrument, as in the difference GMM estimator (DGMM) of Arellano and Bond (1991). Thirdly, the system 
GMM estimator is used, where levels are instrumented with lagged differences, and differences are instrumented with lagged levels. I run two separate versions, where the 2nd, 3rd and 4th lags are used as instruments, and where the 3rd, 4th and 5th lags are used (SGMM24 and SGMM35, respectively). In all GMM cases, outsourcing and the three "classic" production function inputs are all treated as endogenous and thus instrumented by their own lags. The final method is to run a modified version of the OP structural production function, where outsourcing intensity or status is augmented in the production function as a decision variable. This methodology has already been proposed by Amiti and Konings (2007) and extended by Kasahara and Rodrigue (2008). Appendix 2 gives a full explanation of the estimation methodology for the "Mod. OP" estimator. Table 4 presents the results for the estimation of the production function (1) for each treatment of the error term, $\omega_{i t}$ outlined above.

Table 4: International outsourcing intensity enters production function (Dependent variable: Log of output)

\begin{tabular}{rcccccc}
\hline & OLS & FE & DGMM & SGMM35 & SGMM24 & Mod. OP \\
& $(1)$ & $(2)$ & $(3)$ & $(4)$ & $(5)$ & $(6)$ \\
\hline $\mathrm{l}$ & $0.4580^{* * *}$ & $0.4820^{* * *}$ & $0.3804^{* * *}$ & $0.2986^{* * *}$ & $0.2956^{* * *}$ & $0.4171^{* * *}$ \\
(employees) & $(0.0054)$ & $(0.0096)$ & $(0.0119)$ & $(0.0785)$ & $(0.0793)$ & $(0.0056)$ \\
$\mathrm{k}$ & $0.1505^{* * *}$ & $0.0685^{* * *}$ & $0.0712^{* * *}$ & $0.0959^{* *}$ & $0.0901^{*}$ & $0.1070^{* * *}$ \\
(capital) & $(0.0042)$ & $(0.0047)$ & $(0.0053)$ & $(0.0447)$ & $(0.0546)$ & $(0.0028)$ \\
$\mathrm{m}$ & $0.4500^{* * *}$ & $0.2177^{* * *}$ & $0.2661^{* * *}$ & $0.1739^{* * *}$ & $0.1214^{*}$ & $0.4406^{* * *}$ \\
(materials) & $(0.0042)$ & $(0.0052)$ & $(0.0061)$ & $(0.0487)$ & $(0.0724)$ & $(0.0042)$ \\
Outsourcing & $0.0185^{* * *}$ & $0.0081^{* * *}$ & 0.0002 & 0.0029 & 0.0079 & $0.0169^{* * *}$ \\
Intensity & $(0.0012)$ & $(0.0014)$ & $(0.0003)$ & $(0.0043)$ & $(0.0058)$ & $(0.0169)$ \\
$y_{t-1}$ & & & $0.3371^{* * *}$ & $0.5744^{* * *}$ & $0.6075^{* * *}$ & \\
& & & $(0.0325)$ & $(0.0789)$ & $(0.1287)$ & \\
Cons & $5.1607^{* * *}$ & $9.1948^{* * *}$ & $4.0997^{* * *}$ & -0.5557 & 3.2387 & $6.5511^{* * *}$ \\
& $(0.0867)$ & $(0.1957)$ & $(0.5682)$ & $(2.9540)$ & $(2.8776)$ & $(0.2569)$ \\
\hline Obs & 20,220 & 20,220 & 16,312 & 18,266 & 18,266 & 18,261 \\
R-sq & 0.91 & 0.38 &. &. &. & .3265 \\
\hline
\end{tabular}

Standard errors in parentheses

Time and industry dummies included

*** $p \leq 0.01,{ }^{* *} p \leq 0.05, * p \leq 0.1$

The first column of Table 4 shows the basic OLS correlations, where no structure is assumed on the error term whatsoever. Here we see that there is indeed a correlation between outsourcing intensity and output, controlling for production function inputs. The results from Table 4 show that international outsourcing intensity, measured as the ratio of imported material inputs to the total wage bill, has a positive and statistically significant effect on output under the fixed fffects and modified OP treatments of the error term ${ }^{7}$.

\footnotetext{
${ }^{7}$ As an alternative measure of outsourcing intensity, imported materials divided by total materials purchased was used. The results presented in Tables 4 and 5 are not robust to this measure. In particular
} 
I now move on, still in the spirit of Görg et al. (2008), to estimate the production function (1) for each of the three firm types mentioned in Section 3: indigenous non-exporter (Dom), indigenous exporter (Exp), and foreign affiliate (For). The same error term treatments as in Table 4 are employed. Table 5 reports only the coefficient on outsourcing intensity for each estimation of Equation (1) for each of the three firm types. Coefficients on $l, k$ and $m$ are repressed for ease of exposition. In keeping with the findings of Görg et al. (2008), we see that being internationalised leads to a larger benefit from international outsourcing.

Table 5: Effect of international outsourcing intensity; separate regressions for Domestic, Exporting and Foreign firms (Dependent variable: log of output. Coefficient on outsourcing intensity reported)

\begin{tabular}{ccccccc}
\hline & OLS & FE & DGMM & SGMM35 & SGMM24 & $\begin{array}{c}\text { Mod. OP } \\
(1)\end{array}$ \\
& $(1)$ & $(3)$ & $(4)$ & $(5)$ & $(6)$ \\
\hline Dom & $0.0117^{* * *}$ & -0.0001 & 0.0001 & -0.0005 & 0.0143 & $0.0098^{* * *}$ \\
& $(0.0019)$ & $(0.0023)$ & $(0.0003)$ & $(0.0036)$ & $(0.0109)$ & $(0.0019)$ \\
& 10,513 & 10,513 & 8,258 & 9,422 & 9,422 & 9,419 \\
Exp & $0.0140^{* * *}$ & $0.0122^{* * *}$ & $0.0032^{* *}$ & 0.0064 & 0.0043 & $0.0158^{* * *}$ \\
& $(0.0019)$ & $(0.0023)$ & $(0.0015)$ & $(0.0084)$ & $(0.0055)$ & $(0.0019)$ \\
& 7,851 & 7,851 & 6,561 & 7,186 & 7,186 & 7,184 \\
For & $0.0224^{* * *}$ & $0.0224^{* * *}$ & $0.0147^{* * *}$ & $0.0162^{* *}$ & $0.0115^{* *}$ & $0.0271^{* * *}$ \\
& $(0.0032)$ & $(0.0048)$ & $(0.0037)$ & $(0.0064)$ & $(0.0051)$ & $(0.0033)$ \\
& 1,856 & 1,856 & 1,493 & 1,658 & 1,658 & 1,658 \\
\hline
\end{tabular}

Standard errors in parentheses

No. of observations reported below standard errors

$k, m, l$, time and industry dummies included in all regressions

*** $p \leq 0.01,{ }^{* *} p \leq 0.05,{ }^{*} p \leq 0.1$

Foreign affiliates have the largest coefficient under all models, and the coefficient is significant in all estimations. Indigenous exporters have the second largest coefficient in all estimations, and this coefficient is significant under all models apart from the system GMM estimators. Domestic firms only have a significant coefficient under the modified OP treatment of the error term. The results from this section seem to suggest that there is something of an "internationalisation hierarchy" in productivity improvements from international outsourcing - the more embedded you are, the larger the gains you will elicit from a more intense international outsourcing.

\subsection{Outsourcing as a binary variable}

As mentioned in the introduction, when we think about the productivity-enhancing effects of outsourcing, it may not be sufficient to carry out only the analysis presented in Section

we find no significant positive effect for foreign firms. I believe however, given the fact that outsourcing involves the replacement of tasks that could be carried out by labour within the firm, that a measure capturing the "vertical disaggregation" of the firm, such as outsourcing over wages, is a more appropriate measure 
4.2. The treatment of outsourcing as a binary variable, coupled with analysis that focuses on "switchers", i.e. firms that begin to outsource during the sample period, may give us a more complete picture of the performance-shifting effects of international outsourcing. To investigate the effect of outsourcing as a binary variable, I carry out identical analysis to Section 4.2, replacing outsourcing intensity with a dummy for whether or not a firm imports inputs from a non-affiliated supplier at time $t$ in Equation (1). The nature of the binary variable also allows me to extend the analysis beyond that presented in Section 4.2, by including PSM analysis, estimating (DD) coefficients which truly capture the effect of entering into international outsourcing on switching firms. In doing this, I complement the work already carried out for exporting by De Loecker (2007) who includes export status in the OP framework and then estimates matching coefficients for export switchers to show the TFP gains from beginning to export. I will first present the results of the comparable estimations to those in Section 4.2, and then devote some space to explaining the matching procedure, which can be viewed as another, non-regression, way of dealing with the endogeneity between TFP and outsourcing.

Table 6 is comparable with Table 4 above, where outsourcing status, rather than outsourcing intensity, enters into $i_{i t}$ in Equation (1). We see from the results that in the estimations that identify switching firms, i.e. those that run models solely in first differences (FE and DGMM), there is a positive significant effect of outsourcing on productivity. We see here from the OLS results that the simple correlation between outsourcing status and TFP is not even positive, suggesting that being an outsourcer is not necessarily associated with being more productive. The results on DGMM and FE suggest that, as the hyopetheses laid out above and in Sections 1 and 2 suggest, becoming an outsourcer, rather than being one, is associated with higher productivity.

Table 6: Outsourcing status enters the production function (Dependent variable: Log of output) 


\begin{tabular}{rcccccc}
\hline & OLS & FE & DGMM & SGMM35 & SGMM24 & Mod. OP \\
& $(1)$ & $(2)$ & $(3)$ & $(4)$ & $(5)$ & $(6)$ \\
\hline 1 & $0.4415^{* * *}$ & $0.4783^{* * *}$ & $0.3808^{* * *}$ & $0.2599^{* * *}$ & $0.2418^{* * *}$ & $0.4000^{* * *}$ \\
(employees) & $(0.0054)$ & $(0.0096)$ & $(0.0118)$ & $(0.0645)$ & $(0.0736)$ & $(0.0055)$ \\
$\mathrm{k}$ & $0.1471^{* * *}$ & $0.0675^{* * *}$ & $0.0702^{* * *}$ & 0.0556 & 0.0296 & $0.1083^{* * *}$ \\
(capital) & $(0.0042)$ & $(0.0047)$ & $(0.0053)$ & $(0.0367)$ & $(0.0492)$ & $(0.0031)$ \\
$\mathrm{m}$ & $0.4704^{* * *}$ & $0.2205^{* * *}$ & $0.2640^{* * *}$ & $0.1798^{* * *}$ & $0.1819^{* * *}$ & $0.4643^{* * *}$ \\
(materials) & $(0.0040)$ & $(0.0052)$ & $(0.0061)$ & $(0.0459)$ & $(0.0559)$ & $(0.0040)$ \\
Outsourcing & -0.0058 & $0.0321^{* * *}$ & $0.0218^{* * *}$ & 0.0084 & 0.0128 & $-0.0557^{* * *}$ \\
Status & $(0.0076)$ & $(0.0078)$ & $(0.0082)$ & $(0.0383)$ & $(0.0498)$ & $(0.0079)$ \\
$y_{t-1}$ & & & $0.3265^{* * *}$ & $0.5604^{* * *}$ & $0.5970^{* * *}$ & \\
& & & $(0.0336)$ & $(0.0739)$ & $(0.1014)$ & \\
Cons & $5.0106^{* * *}$ & $9.1687^{* * *}$ & $4.2720^{* * *}$ & -0.0781 & 3.5546 & $5.7582^{* * *}$ \\
& $(0.0867)$ & $(0.1957)$ & $(0.5831)$ & $(2.3487)$ & $(2.5293)$ & $(0.3568)$ \\
\hline Obs & 20,220 & 20,220 & 16,312 & 18,266 & 18,266 & 18,261 \\
R-sq & 0.91 & 0.37 &. &. &. & .2943 \\
\hline
\end{tabular}

Standard errors in parentheses

Time and industry dummies included

*** $p \leq 0.01,{ }^{* *} p \leq 0.05,{ }^{*} p \leq 0.1$

Table 7 extends the regressions in Table 6 by showing that there is a heterogeneous effect for domestic, exporting and foreign firms. We now see that a very different picture is emerging to the comparable table using outsourcing intensity, Table 5. We see here that it is domestic firms, who are Irish-owned and serve only the domestic market, that are more productive when they outsource internationally (as evidenced by the positive significant coefficient in the OLS regressions). Furthermore, the FE and DGMM results suggest that domestic firms that switch into outsourcing also see productivity increases compared to firms that do not change status. Thus we see an effect both for being and for becoming outsourcers for firms that were previously not engaged in any international activity. For exporters and foreign affiliates, we see from the OLS and OP regressions that there is in fact a disadvantage to being an outsourcer, and there is no discernible effect to becoming an outsourcer based on the regression attempts to deal with the endogeneity of TFP and outsourcing.

We now see that internationalisation matters, but in a very different way to what is found above. Rather than being more embedded in international markets leading to a larger producitivity-enhancing effect of outsourcing, we see that switching into outsourcing is only beneficial to firms that were previously not engaged in any international activity. The lesson to be taken here seems to be that there is a learning hierarchy, and once firms have already experienced the productivity-enhacing effects of exporting or foreign investment, international sourcing of inputs will not change their performace further. On the other hand, as a "first step" into international activity, outsourcing does act to increase the productivity of domestic firms. 
Table 7: Effect of international outsourcing status; separate regressions for Domestic, Exporting and Foreign firms (Dependent variable: log of output. Coefficient on outsourcing status reported)

\begin{tabular}{ccccccc}
\hline & OLS & FE & DGMM & SGMM35 & SGMM24 & Mod. OP \\
& $(1)$ & $(2)$ & $(3)$ & $(4)$ & $(5)$ & $(6)$ \\
\hline Dom & $0.0227^{* *}$ & $0.0248^{* *}$ & $0.0256^{* *}$ & 0.0675 & 0.0521 & -0.0131 \\
& $(0.0096)$ & $(0.0113)$ & $(0.0104)$ & $(0.0484)$ & $(0.0431)$ & $(0.0101)$ \\
& 10,513 & 10,513 & 8,258 & 9,422 & 9,422 & 9,419 \\
Exp & $-0.0413^{* * *}$ & -0.0037 & 0.0140 & 0.0255 & 0.0506 & $-0.1128^{* * *}$ \\
& $(0.0126)$ & $(0.0130)$ & $(0.0122)$ & $(0.0739)$ & $(0.0886)$ & $(0.0134)$ \\
& 7,851 & 7,851 & 6,561 & 7,186 & 7,186 & 7,184 \\
For & $-0.0776^{*}$ & -0.0041 & -0.0332 & 0.1604 & 0.1595 & $-0.1789^{* * *}$ \\
& $(0.0457)$ & $(0.0346)$ & $(0.0338)$ & $(0.1772)$ & $(0.1274)$ & $(0.0496)$ \\
& 1,856 & 1,856 & 1,493 & 1,658 & 1,658 & 1,658 \\
\hline
\end{tabular}

Standard errors in parentheses

No. of observations reported below standard errors

$k, m, l$, time and industry dummies included in all regressions

*** $p \leq 0.01,{ }^{* *} p \leq 0.05,{ }^{*} p \leq 0.1$

The final piece of empirical analysis exploits the binary nature of the outsourcing status variable and the fact that many firms switch into outsourcing from a given year $t-1$ to year $t$. Using this fact, I run PSM to estimate DD coefficients for firms that switch into outsourcing. I use outsourcing as a "treatment" and deal with the endogeneity problem by including previous period productivity in the estimation of the propensity score, thus accounting for the fact that firms may be more productive before entry into outsourcing, as in Table 3. This method mimicks randomization by creating a counterfactual for what would have been observed if an observation did not enter into a treatment. Initially, among the pool of non-outsourcers at time $t-1$, a propensity score (Rosenbaum and Ruben, 1983) for entry to international outsourcing at time $t$ is estimated as a function of capital, TFP, export status and foreign ownership, controlling for NACE2 industry classification and year dummies:

$$
\operatorname{Pr}\left(\text { Enter }_{t}=1\right)=F\left(\text { TFP }_{t-1}, k_{t-1}, \text { export }_{t-1}, \text { foreign }_{t-1}, \delta_{i}, \delta_{t}\right)
$$

As mentioned above, the inclusion of $T F P_{t-1}$ is vital, as this controls for the fact that more productive firms are more likely to enter into the intermediate import market. As a robustness check, skill intensity and investment were added as additional determinants of the propensity score, with no non-negligible difference to the significance and magnitude of coefficients resulting.

A continued non-outsourcer from $t-1$ to $t$ with the closest propensity score is selected as a match for the outsourcing entrant at time $t$, using the "nearest neighbour" matching method. In robustness checks I also allow for multiple neighbours, and for kernel matching, 
with the qualitative pattern of results remaining intact. The DD procedure ensures that we are estimating treatment effects comparing the effect of switching into outsourcing to what would have happened if the firm had continued to remain a non-outsourcer. Formally it estimates

$$
\beta_{O S}=\left(T F P_{t+s}^{t}-T F P_{t-1}^{t}\right)-\left(T F P_{t+s}^{c}-T F P_{t-1}^{c}\right)
$$

where $t$ are the treatment group, i.e. those that begin to outsource at time $t$, having been non-outsourcers at $t-1$, and $c$ are the control group, i.e. those that were not outsourcing in $t-1$ or in $t$. The term $s=0$ implies the initial year in which the firm switches into outsourcing. I estimate coefficients for $s \in(0,1,2,3)$. In all estimations the control group reported is the amount of firms who were not outsourcing at time $t$ and continued to not outsource at time $t+s$. Not all of these firms are used in the nearest neighbour matching procedure, where only one firm is matched to each treated firm. I merely report the size of the control group to give an indication of the pool from which we can find a match. Taking the differences removes all common shocks which may have affected both outsourcers and non-outsourcers.

The key assumption to identify a "learning from outsourcing" effect is that any unobservable left in the propensity score is uncorrelated with the decision to start outsourcing. Common support is also imposed, so that any observations with a propensity score too far away from their nearest neighbour are dropped. These dropped firms never amount to more than five, indicating the matching procedure does not result in many outliers. Furthermore, for each regression a balancing test has been performed before and after the matching. The t-tests for the mean of TFP, $k$, export and foreign, reported in Appendix 2, indicate in each regression that the matched and control groups do not have significantly differing means.

The results presented in Table 8 present a similar picture to that found in Tables 6 and 7. Coefficients reported are the average treatment effect on the treated (ATT) from the PSM procedure, where the outcome variable is the difference between TFP in time $t+s$ and time $t-1$. The control group in every regression is the pool of firms that are not outsourcing at any given $t-1$, and are still not outsourcing at time $t+s$. Intuitively this control group gets smaller as $s$ gets larger, due to the fact that there are only five years of data, and the fact that some firms may not be outsourcing for some years, and then start outsourcing later. Results are not reported in the fourth column for exporters or the third or fourth column for foreign affiliates due to sample sizes of under twenty firms for switchers in these categories.

Table 8: average treatment effect on the treated for entry to international outsourcing, for all firms and HMY decomposition 


\begin{tabular}{rcccc}
\hline Outcome $=\Delta T F P_{t+s}$ & $\mathrm{~s}=0$ & $\mathrm{~s}=1$ & $\mathrm{~s}=2$ & $\mathrm{~s}=3$ \\
\hline All firms & $0.0168^{* * *}$ & $0.0180^{* * *}$ & $0.0108^{* * *}$ & -0.00317 \\
& $(.0048)$ & $(.0044)$ & $(.0050)$ & $(.0060)$ \\
Treatment & 831 & 391 & 168 & 63 \\
Control & 4,801 & 2,557 & 1,184 & 435 \\
Domestic & $0.0193^{* * *}$ & $0.0199^{* * *}$ & 0.0005 & 0.0081 \\
& $(.0048)$ & $(.0048)$ & $(.0056)$ & $(.0054)$ \\
Treatment & 404 & 182 & 69 & 23 \\
Control & 3,684 & 1,981 & 920 & 290 \\
Exporter & $0.0251^{*}$ & 0.0134 & 0.0147 & \\
Treatment & $(.0120)$ & $(.0084)$ & $(.0104)$ & \\
Control & 647 & 98 & 31 & \\
Foreign & -0.0653 & 271 & 81 & \\
Treatment & $(.0455)$ & $(.03753$ & & \\
Control & 152 & 19 & \\
Results from Nearest Neighbour Matching $(1$ neighbour $)$ \\
Common Support imposed at all times \\
Standard Errors in parentheses \\
No. of observations in treatment and control groups reported \\
$* * * p \leq 0.01$, ** $p \leq 0.05, * p \leq 0.1$ \\
\hline
\end{tabular}

The TFP-enhancing effect of begining to outsource in positive and significant for all firms. When we look at heterogeneous firms we see that the longer-lasting and more statistically significant effect is for domestic firms that were not engaged in any international activity at time $t-1$ or $t^{8}$. In this methodology, we see more of an effect for indigenous exporters, and still no effect for foreign affiliates, which could be explained by the dramatically small samples sizes for switchers, but also gives credence to the "first step" hypothesis laid out in this paper.

From Table 8, the story on becoming an outsourcer remains as in Table 7 - firms that have no previous engagement in international activity are those that have most to gain from beginning to outsource. This confirms the hypothesis laid out throughout this paper on outsourcing's role in productivity improvement. Appendix 3 reports additional methods to test for the robustness of the results presented above. In Table 11 of Appendix 3, similarly to De Loecker (2007), for robustness I show that results are similar when using a "standard OP" TFP measure. When I use a TFP measure backed out of an OP procedure that does not take account of importing ("standard OP"), the pattern of results holds, in that domestic firms now get three periods of TFP growth, exporters now get two periods of growth, while foreign affiliates do not gain in TFP at all following entry into international outsourcing. As an alternative to nearest neighbour matching, I also carry out kernel matching and "nearest two neighbours" matching. The pattern

\footnotetext{
${ }^{8}$ In fact I go further than this, by ensuring that all the way until the $s=3$ period the firms in the sample are those that are still not engaging in exporting. Likewise for the estimations for exporters, I ensure that for all $s$, the firms in the treatment and control and still exporting.
} 
presented above, i.e. that domestic firms have longer and more significant TFP increases than exporters and foreign affiliates, still holds for both of these procedures.

\section{Conclusion}

The main aim of this paper is to investigate the causal effect of international outsourcing on firm TFP. The literature, adopting very different approaches, has generally found that international outsourcing is good for firms' productivity. A significant contribution of this paper is to show that differing methods of measuring international outsourcing, applied to the same data, can come up with widely differing patterns of results. Support is found for the idea that more productive firms select into outsourcing, following Melitz's (2003) logic for exporting, using a random effects probit model. A higher intensity of outsourcing leads to increases in TFP for indigenous exporters and multinational affiliates (Table 5). This conclusion, that the international orientation of firms matters, has been found in previous studies such as Görg et al. (2008). As an alternative to outsourcing intensity, a discrete variable indicating whether or not a firm imports its intermediates is included in the production function. This discrete variable finds support for the hypothesis that domestic-market-serving firms are more likely to benefit from international outsourcing, as other firms will have already experienced productivity improvements from exporting or international investment. As argued above, there are logical reasons to expect a weaker effect for indigenous exporters or foreign affiliates. I interpret these results as a "first step effect", i.e. outsourcing of intermediate inputs has its most pronounced effect on firms when it is their first engagement with international markets.

\section{Acknowledgments}

Financial support from the from the CEPR/Marie Curie Early Training Network on Globalization, Investment and Services Trade "GIST", Science Foundation Ireland "Research Frontiers Program" Grant MAT 017, and Forfás Productivity Research Bursaries for 2008 and 2009 is gratefully acknowledged. I thank Ron Davies for invaluable discussions. I thank Ciara Whelan, Dermot Leahy, Vincent Hogan, Jim Markusen, Paul Devereux, Paul Walsh, Matthew Gobey, Frank Barry, Stefanie Haller, Christian Danne, Svetlana Batrakova, Marc Schiffbauer, Matthieu Crozet, Karl Whelan, Peter Egger, an anonymous referee and participants at the European Doctoral Group in Economics 2008, Copenhagen, the Irish Society for New Economists 2008, Galway, the FIW Research Conference, Vienna 2008 and ESRI research seminar, Dublin, May 2009 for helpful comments.

\section{References}

Amiti, M., Konings, J. (2007). Trade liberalization, intermediate inputs and productivity: Evidence from Indonesia. American Economic Review, 97(5), 1611-1638. 
Amiti, M., Wei, S.J. (2006). Services offshoring and productivity: Evidence from the United States. NBER Working Papers 11926.

Antràs, P. (2003). Firms, contracts and trade structure. Quarterly Journal of Economics, 118 (4), 1375-1418.

Antràs, P., Helpman, E. (2004). Global sourcing. Journal of Political Economy, 112(3), $552-580$.

Arellano, M., Bond, S. (1991). Some tests of specification for Panel Data: Monte Carlo evidence and an application to employment equations. Review of Economic Studies, 58(2), $277-97$.

Baldwin, R. (2006). Globalisation: the great unbundling(s). Contribution to the project "Globalisation Challenges for Europe and Finland", Secretariat of the Economic Council of Finland.

http://hei.unige.ch/ baldwin/PapersBooks/Unbundling_Baldwin_06-09-20.pdf

Bernard, A.B., Jensen, J.B. (1999). Exceptional exporter performance: Cause, effect, or both? Journal of International Economics, 47 (1), 1-25.

Blundell, R., Bond, S. (1998). Initial conditions and moment restrictions in dynamic panel data models. Journal of Econometrics, 87, 11-143.

De Loecker, J. (2007). Do exports generate higher productivity? Evidence from Slovenia. Journal of International Economics, 73 (1), 69-98.

Feenstra, R.C., Hanson, G.H. (1996). Foreign investment, outsourcing and relative wages, in: R.C. Feenstra, G.M. Grossman and D.A. Irwin, eds., Political economy of trade policy: essays in honour of Jagdish Bhagwati 89-127.

Forfás, 2007. Outward direct investment and the Irish economy. http://www.forfas.ie/media/forfas071103_odi-and-irish-economy.pdf

Görg, H., Hanley, A. (2005). International outsourcing and productivity: Evidence from the Irish electronics industry. North American Journal of Economics and Finance, 16 (2), 255-269.

Görg, H., Hanley, A. (2009). Services outsourcing and innovation: an empirical investigation, CEPR Discussion Paper 7390. 
Görg, H., Hanley, A., Strobl, A. (2004). Outsourcing, foreign ownership, exporting and productivity: An empirical investigation with plant-level data. Globalisation, Productivity and Technology Research Paper, No. 8, University of Nottingham.

Görg, H., Hanley, A., Strobl, E. (2008). Productivity effects of international outsourcing: evidence from plant-level data. Canadian Journal of Economics, 41(2) 670-688.

Gorzig, B., Stephan, A. (2002). Outsourcing and firm-level performance. German Institute for Economic Research, Discussion Paper 309.

Grossman, G., Helpman, E. (2002). Integration versus outsourcing in industry equilibrium. The Quarterly Journal of Economics, 117(1), 85-120.

Grossman, G., Helpman, E. (2003). Outsourcing versus FDI in industry equilibrium. Journal of the European Economic Association, 1(2-3), 317-327.

Grossman, G., Helpman, E. (2005). Outsourcing in a global economy. Review of Economic Studies, 72 (1), 135-159.

Helpman, E., Melitz, M., Yeaple, S.R., 2004. Exports versus FDI with heterogenous firms. American Economic Review 94, 300-316.

Hijzen, A., Inui, T., Todo, Y. (2010) Does offshoring pay? Firm-level evidence from Japan. Economic Inquiry, 44 (4), 880-895.

Kasahara, H., Rodrigue, J. (2008). Does the use of imported intermediates increase productivity? Plant-level evidence. Journal of Development Economics, 87 (1), 106-118.

Keller, W. (2004). International technology diffusion. Journal of Economic Literature, $42(3), 752-782$.

Lopez, R. (2006). Imports of intermediate inputs and plant survival, Economics Letters $92(1), 58-62$.

Melitz, M.J. (2003). The impact of trade on intra-industry reallocations and aggregate industry productivity. Econometrica, 71 (6), 1695-1725.

Olley, S.G., Pakes, A. (1996). The dynamics of productivity in the Telecommunications Equipment industry. Econometrica, 64(6) 1263-1297. 
Olsen, K.B. (2006). Productivity impacts of offshoring and outsourcing: A review. OECD STI Working Paper 2006/1.

Rosenbaum, P. R., Rubin, D. B. (1983). The central role of the propensity score in observational studies for causal effects. Biometrika, 70 (1), 41-55.

\section{Appendix 1 - TFP estimation}

A production function is set up in logs as follows:

$$
y_{i t}=\beta_{k} k_{i t}+\beta_{l} l_{i t}+\beta_{m} m_{i t}+\omega_{i t}+\eta_{i t}
$$

where $y_{i t}$ is $\log$ of gross output, $k_{i t}$ is log of capital, $m_{i t}$ is $\log$ of material inputs used and $l_{i t}$ is $\log$ of labour input. The variables $\omega_{i t}$ and $\eta_{i t}$ are unobservable to the econometrician. The difference between the two unobservables is vital to the rest of the model: $\omega_{i t}$ represents shocks that are potentially observable to the firm when it makes its production decisions at time $t$, such as managerial ability, expected down-time of machinery or expected changes in the manufacturing environment. This $\omega_{i t}$ is often referred to as the "productivity shock". $\eta_{i t}$ represent shocks that are unobservable both to the firm and econometrician when the firm makes its production decision at time $t$.

Olley and Pakes (1996), OP from here on, deal with the well-established endogeneity problem between $\omega$ and factor inputs by imposing structure on the firm's behaviour and movement through discrete time. Under certain assumptions, which have been the cause of much concern to econometricians, the following investment function can be inverted, leading to an expression for unobservable productivity.

$$
i_{i t}=f_{t}\left(\omega_{i t}, k_{i t}, d_{i t}\right) \Leftrightarrow \omega_{i t}=f^{-1}\left(i_{i t}, k_{i t}, d_{i t}\right)
$$

where $i_{i t}$ is investment and $d_{i t}$ is the firm's outsourcing status or intensity. This treatment of the firm's outsourcing status is identical to de Loecker's (2007) treatment of exporting. In the traditional OP estimator, $\Phi$ will be a function of investment and capital only.

Stage 1 of this modified OP estimator runs

$$
y_{i t}=\beta_{l} l_{i t}+\beta_{m} m_{i t}+\Phi_{t}\left(i_{i t}, k_{i t}, d_{i t}\right)+\eta_{i t}
$$

where $\Phi_{t}=\beta_{k} k_{i t}+f^{-1}\left(i_{i t}, k_{i t}, d_{i t}\right)$, meaning that $\beta_{k}$ is unidentified in the first stage. The term $\Phi_{t}$ is a polynomial function of the firm's control variables, investment, capital and outsourcing status/intensity. Labour and materials are considered to be variable inputs and can thus be estimated consistently outside of $\Phi$ in stage 1 . 
The next stage accounts for exit from the sample. The probability of exit from the sample is calculated as

$$
\operatorname{Pr}\left(\chi_{i, t+1}=1 \mid I_{t}\right)=\operatorname{Pr}\left(\chi_{i, t+1}=1 \mid \omega_{i t}, \underline{\omega}_{i, t+1},\left(k_{i, t+1}\right)\right)=\hat{P}_{i t}\left(i_{i t}, k_{i t}, d_{i t}\right)
$$

where $\underline{\omega}_{i, t+1}$ is the productivity value in $(t+1)$ that causes the firm to be indifferent between continuing and exiting. Armed with this estimate of the probability of survival, which is allowed to depend on the outsourcing status or intensity of the firm, the last stage identifies a consistent coefficient on capital. It is calculated using a NLLS estimator on the following equation:

$$
y_{i, t+1}-\beta_{l} l_{i, t+1}-\beta_{m} m_{i, t+1}=\beta_{0}+\beta_{k} k_{i, t+1}+g\left(\left(\hat{\Phi}-\beta_{k} k_{i t}\right), \hat{P}_{i, t+1}\right)+\eta_{i t}
$$

This NNLS estimate requires that $\beta_{k}$ be consistent across time. Given that outsourcing was included in the first stage, an estimate for outsourcing is recovered in this third stage

(this of course does not hold in the traditional OP estimator). Given $\Phi$ and $\hat{\beta}_{k} k$ we can back out TFP as $\omega_{i t}=\hat{\Phi}-\hat{\beta}_{k} k_{i t}$.

\section{Appendix 2 - Quality of Propensity Score Matching}

After the PSM analysis of Table 8, it is possible to perform tests of the quality of the matching. Tables 9 and 10 present two statistics for each variable used in calculating the propensity score for each matching procedure. In Table 9 I report the percentage standardised bias reduction (SBR) between the unmatched and matched samples. This essentially gives a measure of how much the matching procedure has driven the treatment and control groups towards both equality of sample means and lower variance. On the vertical column I report for which sample, and which time period, the matching procedure was carried out, while each column after that represents the percentage SBR for each variable used in calculating the propensity score. I do not report the SBR for the industry and year dummies, but rather only for the export dummy, foreign ownership dummy, TFP and capital stock. For the full sample of firms, we see that the matching is very effective. The minimum bias reduction among the four matching procedures on the full sample is 56 percent in many cases reducing the standardised bias by over 90 percent. For the sample of domestic firms, we now only have statistics for TFP and capital, as all firms are non-foreign and non-exporting before and after the matching. Similarly to the full sample, we see that the matching performs strongly, with a minimum bias reduction of 40 percent and many reductions of over 80 and 90 percent. The same is true for exporters, apart from the last period, where the sample size is so low that scores are not even reported. For foreign firms, it is only when we match on 1 period that we have enough observations to say that the match is reliable. For 2 periods, with 
only 19 firms, we actually see increases in the bias after matching, which means nothing can be inferred from the Average Treatment Effect on the Treated from this procedure.

Table 10 then reports the p-values from the t-tests on equality of means for explanatory variables in the control and treatment groups. A p-value above .05 indicates that equal means cannot be rejected. As we see below, in all cases for which results are reported in Table 8, the matching procedure cannot reject that means are equal after the matching has been done, indicating that the match is of a sufficiently high quality.

Table 9: percentage reduction in standardised bias for each propensity score explanatory

\begin{tabular}{rr|cccc}
\multicolumn{5}{c}{ variable for all regressions reported in Table 8.} \\
\hline Sample & $s$ & Foreign & Export & TFP & Capital \\
& & & & & \\
All & 0 & 56.1 & 93.4 & 87.4 & 93.5 \\
All & 1 & 80.6 & 100 & 82.1 & 91.2 \\
All & 2 & 59 & 100 & 79.3 & 97.8 \\
All & 3 & 84.4 & 100 & 58.3 & 74.3 \\
& & & & & \\
Dom & 0 & $\mathrm{n} / \mathrm{a}$ & $\mathrm{n} / \mathrm{a}$ & 90.5 & 85.7 \\
Dom & 1 & $\mathrm{n} / \mathrm{a}$ & $\mathrm{n} / \mathrm{a}$ & 93.2 & 92.4 \\
Dom & 2 & $\mathrm{n} / \mathrm{a}$ & $\mathrm{n} / \mathrm{a}$ & 40.5 & 81.6 \\
Dom & 3 & $\mathrm{n} / \mathrm{a}$ & $\mathrm{n} / \mathrm{a}$ & 98.5 & 93.7 \\
& & & & & \\
Exp & 0 & $\mathrm{n} / \mathrm{a}$ & $\mathrm{n} / \mathrm{a}$ & 84.8 & 78.3 \\
Exp & 1 & $\mathrm{n} / \mathrm{a}$ & $\mathrm{n} / \mathrm{a}$ & 55.8 & 73.9 \\
Exp & 2 & $\mathrm{n} / \mathrm{a}$ & $\mathrm{n} / \mathrm{a}$ & 86.9 & 97.3 \\
Exp & 3 & $\mathrm{n} / \mathrm{a}$ & $\mathrm{n} / \mathrm{a}$ & $\mathrm{n} / \mathrm{a}$ & $\mathrm{n} / \mathrm{a}$ \\
& & & & & \\
For & 0 & $\mathrm{n} / \mathrm{a}$ & 58.2 & 76.4 & 95.9 \\
For & 1 & $\mathrm{n} / \mathrm{a}$ & $\mathrm{n} / \mathrm{a}$ & -74.8 & -204.4 \\
For & 2 & $\mathrm{n} / \mathrm{a}$ & $\mathrm{n} / \mathrm{a}$ & & \\
For & 3 & $\mathrm{n} / \mathrm{a}$ & $\mathrm{n} / \mathrm{a}$ & & \\
\hline
\end{tabular}

\section{Appendix 3 - Robustness checks}

The Census of Industrial Production comprises differing survey forms for plants which form an enterprise (single-plant firms) and plants that are part of a multi-plant enterprise. Importantly for this study, for plants that are part of a multi-plant enterprise, the question regarding the percentage of purchases coming from affiliated firms is only asked to the enterprise and not to the plant. The figure reported in the data for affiliate purchases for such plants is in fact a statistical imputation carried out by the Central Statistics Office (CSO). Of the plants in the data, a very significant proportion (93\% of domestic 
firms, $93 \%$ of exporters, $84 \%$ of foreign affiliates) are single-plant firms in Ireland, which means this is not a major issue. In any case, any bias resulting from potentially erroneous imputation should be accounted for. I take all firms for whom the total enterprise value for affiliate purchases was zero. This means that the CSO's imputed value for each plant within the enterprise will be zero, thus leaving no imputation worries. I run all regressions on all these firms, with minimal change from the regressions reported in Sections 4.1 and 4.2. With this robustness check, this data worry should be assuaged.

Table 10: $p$-values for t-tests of equality of means between matched treatment and control groups for all PSM reported in Table 8. $p>.05$ implies identical means cannot be rejected at 5 percent level

\begin{tabular}{rc|cccc}
\hline Sample & $s$ & Foreign & Export & TFP & Capital \\
& & & & & \\
All & 0 & .124 & .580 & .494 & .630 \\
All & 1 & .646 & 1.000 & .501 & .550 \\
All & 2 & .480 & 1.000 & .553 & .904 \\
All & 3 & .785 & 1.000 & .251 & .437 \\
& & & & & \\
Dom & 0 & $\mathrm{n} / \mathrm{a}$ & $\mathrm{n} / \mathrm{a}$ & .746 & .509 \\
Dom & 1 & $\mathrm{n} / \mathrm{a}$ & $\mathrm{n} / \mathrm{a}$ & .810 & .746 \\
Dom & 2 & $\mathrm{n} / \mathrm{a}$ & $\mathrm{n} / \mathrm{a}$ & .155 & .498 \\
Dom & 3 & $\mathrm{n} / \mathrm{a}$ & $\mathrm{n} / \mathrm{a}$ & .982 & .887 \\
& & & & & \\
Exp & 0 & $\mathrm{n} / \mathrm{a}$ & $\mathrm{n} / \mathrm{a}$ & .880 & .499 \\
Exp & 1 & $\mathrm{n} / \mathrm{a}$ & $\mathrm{n} / \mathrm{a}$ & .822 & .500 \\
Exp & 2 & $\mathrm{n} / \mathrm{a}$ & $\mathrm{n} / \mathrm{a}$ & .727 & .960 \\
Exp & 3 & $\mathrm{n} / \mathrm{a}$ & $\mathrm{n} / \mathrm{a}$ & $\mathrm{n} / \mathrm{a}$ & $\mathrm{n} / \mathrm{a}$ \\
& & & & & \\
For & 0 & $\mathrm{n} / \mathrm{a}$ & .770 & .546 & .951 \\
For & 1 & $\mathrm{n} / \mathrm{a}$ & $\mathrm{n} / \mathrm{a}$ & .323 & .209 \\
For & 2 & $\mathrm{n} / \mathrm{a}$ & $\mathrm{n} / \mathrm{a}$ & $\mathrm{n} / \mathrm{a}$ & $\mathrm{n} / \mathrm{a}$ \\
For & 3 & $\mathrm{n} / \mathrm{a}$ & $\mathrm{n} / \mathrm{a}$ & $\mathrm{n} / \mathrm{a}$ & $\mathrm{n} / \mathrm{a}$ \\
\hline
\end{tabular}

As an alternative to breaking the data down by HMY into indigenous non-exporters, indigenous exporters and foreign affiliates, as in Tables 5 and 7, I run a single regression in which the outsourcing variable in question is interacted with a dummy for each HMY category. This allows the effect of being in different HMY categories to be pinned down by ensuring that the intercept and coefficients on $l, k$ and $m$ are identical for all firms. The results of this robustness check for Tables 5 and 7 show that, across all specifications, whether the coefficients on the production inputs are allowed to differ across HMY categories has almost no impact: the coefficients on the interacted outsourcing term are almost identical to three decimal places to the corresponding subgroup coefficients in Table 5 for outsourcing intensity and are similar, usually identical to a minimum of two 
decimal places for all except Difference GMM for domestic firms in Table 7 for outsourcing status.

I also test whether the PSM results are sensitive to the usage of an alternative measure of productivity. Rather than use TFP $P_{i m}$, the productivity measure backed out of a OP procedure in which the import status of the firm is included as a decision variable, I run the same PSM procedures using a simple $T F P_{o p}$, the TFP backed out of a "classic" OP estimation where importing is not accounted for. The results, presented in Table 11, are broadly similar to those presented in Table 8, with more significant coefficients in Table 11. Rather than two periods of TFP growth, domestic firms experience three periods of growth when using this measure. Similarly, rather than one period of growth, exporters gain for two periods in this instance. The pattern of results, i.e. the longer-lasting effect for domestic firms, still holds however.

Table 11: average treatment effect on the treated for entry to international outsourcing, for all firms and HMY decomposition using "standard" OP TFP

\begin{tabular}{rcccc}
\hline Outcome $=\Delta T F P_{t+s}$ & $\mathrm{~s}=0$ & $\mathrm{~s}=1$ & $\mathrm{~s}=2$ & $\mathrm{~s}=3$ \\
\hline All firms & $.0158^{* * *}$ & $.0141^{* * *}$ & .0050 & -.0053 \\
&.$(0048)$ & $(.0042)$ & .0051 & $(-.086)$ \\
Treatment & 831 & 391 & 168 & 63 \\
Control & 4801 & 2557 & 1184 & 435 \\
Domestic & $.0157^{* * *}$ & $.0180^{* * *}$ & $.0121^{* *}$ & .0026 \\
& $(.0048)$ & $(.0054)$ & $(.0061)$ & $(.0054)$ \\
Treatment & 404 & 182 & 69 & 23 \\
Control & 3684 & 1981 & 920 & 290 \\
Exporter & $.0270^{* * *}$ & $.0273^{* * *}$ & .0137 & \\
Treatment & $(.0120)$ & $(.0108)$ & .0087 & \\
Control & 647 & 98 & 31 & \\
Foreign & -.0734 & -.0003 & 81 & \\
Treatment & $(.0448)$ & .0575 & \\
Control & 152 & 19 & \\
Results from Nearest Neighbour Matching \\
Common Support imposed at all times \\
Standard Errors in parentheses \\
No. of observations in treatment and control groups reported \\
$* * * p \leq 0.01$, ** $p \leq 0.05, * p \leq 0.1$ \\
\hline
\end{tabular}

Finally, I also test the robustness of the results to alternative measures of matching. Under kernel matching, we see that results are much more often significant. Domestic firms have four periods of TFP growth in this instance, while affiliates have three periods of growth. Again, the pattern that outsourcing matters more for domestic firms still holds, although the statement seems less strong when exporters also gain for three periods. Similarly, using "nearest two neighbours" matching, we see that domestic firms experience 
significant TFP growth over one, two and four periods after entering outsourcing, while exporters experience growth over one, two and three periods. This again supports the statement that the effects of outsourcing on TFP are felt longest by domestic firms. 